\author{
KRZYSZTOF CHMIELEWSKI (Poznań) \\ MACIEJ PAJĄK (Poznań)
}

\title{
Organizacja więziennictwa polskiego (1918-1939)
}

System więzienny stanowi część aparatu administracyjnego państwa. Regulacja prawa administracyjnego $\mathrm{w}$ dziedzinie systemu penitencjarnego dotyczy m.in.: usytuowania więziennictwa $\mathrm{w}$ administracji państwowej, struktury organizacyjnej (organ kierowniczy, jednostki podstawowe, organ pośredni oraz jego struktura, organ kontrolny i nadzorujący), organów nadzoru zewnętrznego (nadzór prokuratorski, sądowy), doboru, stratyfikacji i szkolenia personelu.

Celem tego artykułu jest przybliżenie podstawowych problemów funkcjonowania i organizacji polskiego więziennictwa okresu międzywojennego. Opisując kształtowanie się polskiego systemu penitencjarnego nie można abstrahować od uwarunkowań politycznych, które w istotny sposób przyczyniły się do recepcji niektórych rozwiązań, typowych dla systemów prawnych państw zaborczych. W dalszej części artykułu zostanie przedstawione znaczenie międzynarodowych kongresów penitencjarnych dla polskiego systemu więziennego okresu międzywojennego.

\section{POLONIZACJA WIĘZIENNICTWA}

Dla początków polskiego więziennictwa kluczowe znaczenie miała kwestia jego polonizacji, tzn. przejęcia zarządu więzień od władz okupacyjnych. We wrześniu 1917 r. państwa okupacyjne (Niemcy i Austria) podjęły decyzję o przekazaniu sądownictwa pod polską kontrolę ${ }^{1}$. Zadanie zorganizowania więziennictwa powierzono Ministerstwu Sprawiedliwości, w ramach którego utworzono Wydział Więzienny. Początkowo realizował on powierzone zadanie we współpra-

\footnotetext{
${ }^{1}$ K. Pawlak, Więziennictwo Polskie w latach 1918-1939, Kalisz 1995, s. 7.
} 
cy z Wydziałem Administracyjnym, natomiast od maja 1918 r. już samodzielnie ${ }^{2}$. W lipcu 1918 r. funkcje Wydziału przejęła Sekcja Więzienna, także usytuowana w strukturze organizacyjnej Ministerstwa Sprawiedliwości. Kompetencje Sekcji skupiały się wokół problematyki formułowania projektów przepisów oraz szkolenia przyszłej kadry kształtującego się polskiego więziennictwa. W założeniu szkolenie miało być podzielone na część teoretyczną oraz praktyczną. Pierwsza odbywała się w ramach Sekcji, natomiast praktyczna w więzieniach niemieckich. Kierownictwo Sekcji powierzono Janowi Zakrzewskiemu. ${ }^{3}$

Polonizacja więziennictwa miała być wynikiem przejmowania zarządu nad więzieniami na terenach okupowanych. Proces przejmowania zarządu cechował różny stopień skomplikowania w zależności od terenów, na których miał miejsce. Wpłynęły na to m.in. różne nastawienie byłych władz okupacyjnych do przedmiotowej kwestii, różne systemy prawne, w których funkcjonowały przejmowane więzienia oraz różna sytuacja polityczna $\mathrm{w}$ poszczególnych regionach odradzającego się państwa polskiego. Tytułem przykładu, przejęcie dwunastu jednostek izolacyjnych na obszarze Górnego Śląska nastąpiło dopiero w listopadzie 1922 r. $^{4}$

W sumie przejęto zarząd nad 33 dużymi więzieniami, 98 mniejszymi jednostkami oraz 269 aresztami przy sądach powiatowych. ${ }^{5}$ Stan przejętych jednostek pozostawiał wiele do życzenia. Budynki wymagały gruntownego remontu, pomieszczenia nie były we właściwy sposób ogrzewane oraz nie zapewniały odpowiedniej cyrkulacji powietrza ${ }^{6}$.

Systemy penitencjarne państw zaborczych były nastawione na realizację założeń represyjnej koncepcji kary więzienia. Tym samym nie było możliwe wykonywanie kary w duchu idei resocjalizacyjnych, krystalizujących się we współczesnej penitencjarystyce. Zarówno stan więzień, jak i nowe prądy w nauce o więziennictwie niosły ze sobą konieczność przebudowy infrastruktury więziennej oraz zmiany myślenia o funkcjach i celu kary więzienia.

Początkowo podstawą prawną działania polskiego więziennictwa były przepisy wydane jeszcze pod rządami państw zaborczych. Na terenie byłego zaboru niemieckiego obowiązywały przepisy ordynacji więziennej z 1898 r. Z kolei na terenie byłego zaboru austriackiego obowiązywały postanowienia ustawy dotyczącej postępowania karnego z 23 maja 1873 r. oraz regulaminy więzienne. Funkcjonowanie więzień na terenie byłego zaboru rosyjskiego opierało się na przepisach ustawy o więzieniach z 1890 r. oraz ustawy o zakładach wychowawczo-poprawczych dla nieletnich z 1909 r. ${ }^{7}$

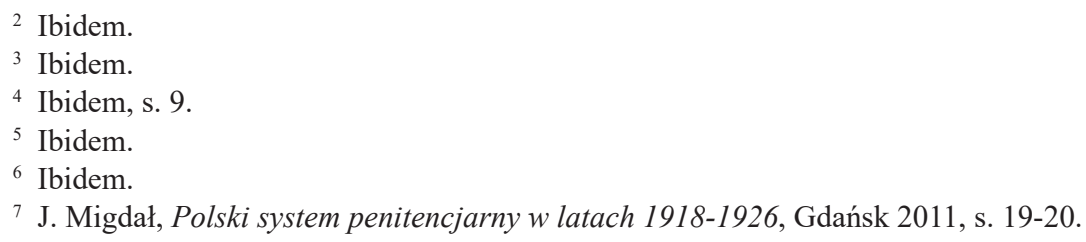


Normatywny chaos potęgowało również różne rozumienie roli i powiązania więziennictwa $\mathrm{z}$ administracją państwową. Na terenie byłego zaboru austriackiego i niemieckiego traktowano więziennictwo jako element wymiaru sprawiedliwości. W byłym zaborze rosyjskim postrzegano system więzienny jako element większej całości, czyli systemu administracji państwowej ${ }^{8}$.

Mając na uwadze konieczność unifikacji przepisów regulujących organizację systemu penitencjarnego, 8 lutego 1919 r. Naczelnik Państwa wydał dekret $\mathrm{w}$ sprawie tymczasowych przepisów więziennych obowiązujących na ziemiach byłego zaboru rosyjskiego". Prawie równocześnie, bo już 7 lutego 1919 r., także dekretem Naczelnika Państwa, ustanowiono okręgowe dyrekcje więzienne. ${ }^{10}$

Drugim aktem normatywnym dotyczącym organizacji więziennictwa było rozporządzenie Prezydenta Rzeczypospolitej z dnia 7 marca 1928 r. w sprawie organizacji więziennictwa. ${ }^{11}$ Jego postanowienia znalazły realizację w przepisach Regulaminu więziennego z 1931 r. Przyjął on formę rozporządzenia Ministra Sprawiedliwości ${ }^{12}$.

Ostatnim aktem normatywnym okresu międzywojennego poświęconym problematyce organizacji systemu penitencjarnego była ustawa $\mathrm{z}$ dnia 26 lipca 1939 r. w sprawie organizacji więziennictwa ${ }^{13}$. W literaturze podkreśla się, iż wprowadzała $\mathrm{w}$ życie wiele rozwiązań propagowanych przez wybitnych przedstawicieli polskiej doktryny penitencjarnej, np. Zygmunta Bugajskiego ${ }^{14}$.

\section{STRUKTURA ORGANIZACYJNA WIĘZIENNICTWA W LATACH 20.}

Od pierwszych lat niepodległości struktura organizacyjna więziennictwa nie była skomplikowana. Doceniano ją przede wszystkim za sprawność działania ${ }^{15}$. Ze względu na potrzebę szybkiego zorganizowania podstaw działania systemu penitencjarnego większość kompetencji w zakresie szkolenia przyszłych funkcjonariuszy oraz nadzoru nad instytucjami izolacyjnymi skupiono w Sekcji Więziennej. ${ }^{16}$ Dopiero po osiągnięciu stabilizacji więziennictwa zdecydowano się podjąć kroki w kierunku jego decentralizacji. Nastąpiła ona poprzez utworzenie pięciu Dyrekcji Okręgo-

\footnotetext{
${ }^{8}$ K. Pawlak, op.cit., s. 9.

9 Dz.U. 1919, Nr 15, poz. 202.

${ }^{10}$ Dz.U. 1919, Nr 14, poz. 173.

11 Dz. U. 1928, Nr 29, poz. 272.

12 Dz.U. 1931, Nr 71, poz. 577.

13 Dz. U. 1939, Nr 69, poz. 457.

14 J. Śliwowski, Prawo i polityka penitencjarna, Warszawa 1982, s. 75.

15 K. Pawlak, op.cit., s. 11.

16 M. Czerwiec, Więzienioznawstwo. Zarys rozwoju więziennictwa, Warszawa 1958, s. 209.
} 
wych: w Warszawie, Łodzi, Siedlcach, Lublinie i Kielcach ${ }^{17}$. W 1920 r. utworzono dwie dodatkowe Dyrekcje Okręgowe dla terenów byłego zaboru austriackiego z siedzibą w Krakowie i we Lwowie ${ }^{18}$. Głównym zadaniem Dyrekcji była kontrola gospodarcza i finansowa więzień. Warto zaznaczyć, że Dyrekcje nie istniały na terenie byłego zaboru niemieckiego, gdzie więzienia podlegały Ministerstwu byłej Dzielnicy Pruskiej ${ }^{19}$. Dyrekcje miały pełnić funkcję organu pośredniego między więzieniami a Sekcją Więzienną, przekształconą później w Departament Więzienny. Pomimo wyraźnego usprawnienia działania administracji więziennej, Dyrekcje Okręgowe zostały zlikwidowane jesienią $1921 \mathrm{r}$. ze względu na brak środków finansowych.

W ramach Sekcji Więziennej funkcjonowało sześć wydziałów: osobowy, gospodarstwa więziennego, administracyjny, penitencjarny, biuro rachuby, kancelaria oraz centralna kasa. Sekcja pełniła rolę swoistego centralnego zarządu więziennictwa ${ }^{20}$. Jak już wspomniano, w 1921 r. Sekcja Więzienna została przekształcona w Departament Więzienny. Wiązało się to z koniecznością redukcji etatów w Sekcji oraz z wewnętrzną reorganizacją Ministerstwa Sprawiedliwości. Po przekształceniu Departament składał się z trzech wydziałów: administracji więzień, służbowego oraz pracy więźniów, a także z kancelariii ${ }^{21}$. Koniec lat trzydziestych przyniósł ze sobą kolejne przekształcenia struktury Departamentu Więziennego. W miejsce wydziału służbowego utworzono wydział penitencjarny. Ponadto ustanowiono trzy referaty: inspekcji i dochodzeń, higieny i lecznictwa oraz służby penitencjarnej ${ }^{22}$. Pracami Departamentu kierowali: Jan Zakrzewski, Franciszek Głowacki, Witold Paszkowski, Zygmunt Głowacki, Władysław Augustynowicz, Lucjan Jaxa-Maleszewski, Michał Lorentowicz, Stanisław Turowicz, Aleksander Chruścicki, Tadeusz Mitraszewski oraz Tadeusz Krychowski²3.

\section{KLASYFIKACJA WIĘZIEŃ W LATACH 20.}

Najważniejsza z punktu widzenia organizacji międzywojennego więziennictwa była kwestia podziału więzień. W niej przejawiało się między innymi to, jaką koncepcję więzienia preferuje polski ustawodawca. Podział więzień na poszczególne kategorie pokazał także, że polski system penitencjarny wypracował instytucje charakterystyczne wyłącznie dla niego, nie zaczerpnięte z systemów prawnych państw zaborczych.

\footnotetext{
${ }^{17}$ Ibidem.

${ }^{18}$ K. Pawlak, op.cit., s. 10.

19 Ibidem.

${ }^{20}$ M. Czerwiec, op.cit., s. 210.

21 J. Migdał, op.cit., s. 269.

${ }^{22}$ K. Pawlak, op.cit., s. 9.

${ }^{23}$ Ibidem, s. 10.
} 
Dekret Naczelnika Państwa z 1919 r. nie poruszał kwestii klasyfikacji więzień. Jedynie $\mathrm{w}$ art. 1 tegoż dokumentu wspominano o podziale na więzienia oraz zakłady wychowawczo-poprawcze. W sposób bardziej szczegółowy problematyka klasyfikacji więzień została uregulowana w rozporządzeniu Prezydenta Rzeczypospolitej z dnia 7 marca 1928 r. w sprawie organizacji więziennictwa. Rozporządzenie dzieliło więzienia na samodzielne oraz przy sądach grodzkich ${ }^{24}$. Ze względu na pojemność samodzielnych jednostek penitencjarnych oraz długość orzeczonej kary, rozporządzenie dzieliło więzienia na trzy klasy. Więzienia I klasy były przeznaczone dla skazanych na kary powyżej 3 lat izolacji więziennej, a ich pojemność przekraczała 450 osób. II klasa obejmowała więzienia dla skazanych na kary od 1 do 3 lat. W takich więzieniach karę miało odbywać od 150 do 450 osadzonych. Ostatnia, III klasa, była przeznaczona dla skazanych na kary poniżej 1 roku. Więzienia tej klasy cechowała również najmniejsza pojemność. W założeniu, jednostki III klasy miały mieścić do 150 osadzonych. Klasyfikację więzień dzielono w doktrynie na formalną oraz faktyczną, która dotyczyła segregacji więźniów ze względu na różne kryteria, m.in. wiek, płeć oraz charakter popełnionego przestępstwa ${ }^{25}$. Taki sposób podziału więzień miał sprzyjać osiągnięciu celów nowej koncepcji kary, jakimi były przede wszystkim poprawa sprawcy przestępstwa oraz jego społeczna reintegracja.

Zmiany w dziedzinie klasyfikacji więzień wprowadziło uchwalenie nowego Regulaminu więziennego w 1931 r. oraz Kodeksu karnego w 1932 r. Zniesiono różne formy kary więzienia, które występowały w ustawodawstwie karnym państw zaborczych, wprowadzając w ich miejsce karę w formie aresztu albo więzienia $^{26}$. W $\S 235$ rozporządzenia wprowadzono nowy typ zakładów karnych, tj. więzienia izolacyjne. Zgodnie z brzmieniem przepisu, takie więzienia były przeznaczone dla przestępców zawodowych, nałogowych, recydywistów oraz ukaranych dyscyplinarnie. Co więcej, środki wychowawczo-poprawcze stosowane w zwykłych więzieniach wobec przestępców okazały się nieskuteczne, a wpływ tychże przestępców na innych osadzonych mógłby być szkodliwy. Z grona osób, które można było umieścić w więzieniu izolacyjnym $\S 236$ rozporządzenia wyłączał kobiety, duchownych, osoby poniżej 21 roku życia, skazanych na areszt lub karę twierdzy oraz więźniów śledczych. O przeniesieniu do więzienia izolacyjnego decydował Minister Sprawiedliwości na wniosek prokuratora albo właściwego naczelnika więzienia. Warto wspomnieć, że w ramach więzień izolacyjnych funkcjonował swoisty progresywny system wykonywania kary więzienia. Więźniów dzielono na dwie klasy. Po przyjęciu więźniowie byli przydzielani do klasy

\footnotetext{
${ }^{24}$ Ibidem, s. 20.

${ }^{25}$ M. Czerwiec, op.cit., s. 219.

${ }^{26}$ K. Pawlak, op.cit., s. 22.
} 
pierwszej, w której panował większy rygor niż w klasie drugiej. Okres pobytu w pierwszej klasie wynosił 3 miesiące. Awans do klasy drugiej był uzależniony od wykazywanego stopnia poprawy. Zgodnie z § 237 Regulaminu więziennego z 1931 r., okres pobytu w tej klasie wynosił 9 miesięcy. W przypadku nienagannego zachowania więźniów i jeżeli do końca kary pozostawało co najmniej 6 miesięcy, mogli być oni przeniesieni do zwykłego więzienia ${ }^{27}$.

\section{KLASYFIKACJA WIĘZIEŃ W LATACH 30.}

W latach trzydziestych powstawały nowe typy zakładów karnych, co stanowiło realizację postulatów resocjalizacyjnych, coraz mocniej propagowanych w polskiej penitencjarystyce. Nowe rozwiązania $\mathrm{w}$ dziedzinie klasyfikacji więzień ujęto w ramy prawne poprzez uchwalenie ustawy o organizacji więziennictwa z 26 lipca 1939 r. Przywołana ustawa nie mogła zostać sprawdzona w praktyce funkcjonowania systemu penitencjarnego, ponieważ kilka dni po jej uchwaleniu wybuchła II wojna światowa. W sferze koncepcyjnej ustawa o organizacji więziennictwa stanowiła istotny krok naprzód w myśleniu o roli więziennictwa. Mocą przepisów tej ustawy potwierdzono podział aresztów na śledcze dla tymczasowo aresztowanych oraz karne. Więzienia podzielono na zwykłe i specjalne. Do specjalnej kategorii więzień ustawa zaliczała zakłady obserwacyjno-rozdzielcze, penitencjarne zakłady lecznicze, więzienia izolacyjne, kolonie rolnicze, więzienia-zakłady rzemieślnicze, zakłady dla nieletnich oraz karne ruchome ośrodki pracy. ${ }^{28}$ Zakłady obserwacyjno-rozdzielcze były przeznaczone do przeprowadzania stosownych badań osobowościowych, które umożliwiały skierowanie do odpowiedniego za$\mathrm{kładu}^{29}$. Kolonie rolnicze były miejscem odbywania kary dla skazanych na karę w wymiarze od 1 do 5 lat, którzy pochodzili ze środowisk wiejskich. Ponadto osoby odbywające karę w koloniach rolniczych musiały być karane po raz pierwszy oraz mieć nie więcej niż 30 lat. Kolonie funkcjonowały już od 1934 r. Ustawa tworzyła podstawę prawną dla ich działania. Kryteria kwalifikujące skazanych do odbywania kary w więzieniach-zakładach rzemieślniczych były identyczne, jak w przypadku kolonii rolniczych. Jedyny wyjątek stanowił wymóg, aby skazani pochodzili z miast ${ }^{30}$.

Karne ruchome ośrodki pracy, tak jak pozostałe dwa typy specjalnych zakładów karnych, stworzono z myślą o wyeliminowaniu problemu przeludnienia

27 L. Rabinowicz, Podstawy nauki o więziennictwie, Warszawa 1933, s. 97.

${ }^{28}$ M. Czerwiec, op.cit., s. 227-229.

29 J. Górny, Penitencjarystyka. Główne problemy wykonania kary pozbawienia wolności w rozwoju historycznym, Warszawa 1981, s. 271.

${ }^{30}$ K. Pawlak, op.cit., s. 58. 
w polskim więziennictwie. Były przeznaczone dla skazanych na karę więzienia w wymiarze od 6 miesięcy do roku w wieku do 45 lat oraz dla przypadkowych przestępców, którzy byli skazywania raz lub dwukrotnie za to samo przestępstwo, a do końca kary pozostawało im mniej niż 4 miesiące $^{31}$. Zaczęto je organizować w 1936 r. Ich cechą charakterystyczną było to, że działały w okresie od kwietnia do listopada ${ }^{32}$. Ośrodki miały również przyczynić się do likwidacji problemu niewykonywania krótkoterminowych wyroków ${ }^{33}$.

Poszczególne typy zakładów karnych różniły się między sobą rygorem, organizacją wewnętrzną oraz metodami postępowania wobec sprawców przestępstw $^{34}$. Mimo zauważalnych odrębności we wspomnianych wyżej dziedzinach, widoczne w całej organizacji systemu więziennego było dążenie do realizacji idei indywidualizacji kary. Dobitnym tego przykładem było wstępne badanie osobowości skazanych w zakładach obserwacyjno-rozdzielczych oraz utworzenie już w 1933 r. Komisji do Badań Kryminalno-Biologicznych w Ministerstwie Sprawiedliwości ${ }^{35}$.

\section{STRUKTURA WIĘZIEŃ}

Innym aspektem organizacji systemu więziennego jest zagadnienie struktury wewnętrznej jego jednostki podstawowej, jaką jest więzienie. W okresie międzywojennym wykształcił się pewien model takiej struktury.

Art. 10 rozporządzenia Prezydenta Rzeczypospolitej z dnia 7 marca 1928 r. w sprawie organizacji więziennictwa zaliczał do personelu więziennego (,składu osobowego więzienia” w terminologii rozporządzenia): naczelnika więzienia oraz w miarę potrzeby pomocników naczelnika, asystentów więziennych, urzędników kancelaryjnych oraz dozorców i dozorczynie ${ }^{36}$. W więzieniach I i II klasy przewidziano obowiązek zatrudnienia duchownych, nauczycieli i lekarzy jako pracowników kontraktowych. W więzieniach III klasy ich zatrudnienie miało charakter fakultatywny (art. 11 rozporządzenia). Naczelnicy więzień byli mianowani przez Ministra Sprawiedliwości, natomiast mianowanie niższych funkcjonariuszy więziennych wchodziło w zakres kompetencji naczelników więzień. Zgodnie $\mathrm{z}$ art. 9 rozporządzenia, naczelnik był przełożonym wszystkich urzędników

31 Ibidem, s. 59.

${ }^{32}$ Ibidem.

${ }_{33}$ T. Mitraszewski, Projekt ustawy o organizacji więziennictwa, „Przegląd Więziennictwa Polskiego" 1937, nr 1, s. 23.

${ }^{34}$ M. Czerwiec, op.cit., s. 229.

${ }^{35}$ J. Górny, op.cit. s. 269.

${ }_{36}$ Z. Bugajski, Podręcznik do egzaminu z zakresu więziennictwa praktycznego dla dozorców więziennych cz.1, Warszawa 1930, s.7. 
i funkcjonariuszy więziennych, egzekwował odpowiedzialność dyscyplinarną wobec nich oraz kierował administracją i gospodarstwem więzienia.

Niewielkie zmiany w przedmiocie wewnętrznej struktury więzień wprowadzał Regulamin więzienny z 1931 r. Także w nim znajdują się przepisy, zaliczające do personelu więziennego naczelnika, pomocników naczelnika więzienia, asystentów, personel kancelaryjny, niższych funkcjonariuszy, tj. starszych dozorców, starsze dozorczynie, dozorców i dozorczynie oraz kapelanów, lekarzy i nauczycieli jako pracowników kontraktowych (§ 1 rozporządzenia). W § 14 Regulaminu określono naczelnika jako przełożonego więzienia, powierzono mu kierownictwo wszystkimi działami służby. Ponadto naczelnikowi przysługiwało prawo nakładania kar, w granicach obowiązujących przepisów, wobec więźniów oraz podwładnych funkcjonariuszy. Naczelnik był odpowiedzialny za utrzymanie spokoju i porządku w więzieniu. Ciążył na nim także obowiązek wykonywania orzeczeń, decyzji i nakazów uprawnionych władz. Do zadań naczelnika należało dbanie o racjonalną organizację pracy więźniów i racjonalne gospodarowanie środkami finansowymi więzienia. Naczelnik dokonywał podziału czynności między funkcjonariuszy oraz był obowiązany do dziennych i nocnych inspekcji jednostki. Odpowiadał również za rachunkowość oraz sprawy biurowe.

Regulamin przewidywał w $\S 22$ utworzenie czterech działów w każdym więzieniu, tj. administracyjnego, pracy więźniów, gospodarczego i wychowawczego. Do pomocy w zarządzaniu poszczególnymi działami naczelnik mógł wyznaczyć pomocnika, asystentów więziennych lub urzędników kancelaryjnych. Obowiązki pomocników naczelnika dotyczyły różnych spraw z zakresu bieżącego administrowania więzieniem, m.in. prowadzenia ksiąg i akt więzienia, sporządzania statystyki oraz czuwania nad właściwym rozmieszczeniem więźniów. Obowiązki pomocników były zróżnicowane w zależności od działu, w którym pracowali.

Kolejną część personelu stanowili starsi dozorcy oraz dozorcy. Starsi dozorcy byli bezpośrednimi zwierzchnikami dozorców więziennych. Wykonując polecenia naczelnika mogli udzielać im pouczeń oraz sprawować nadzór nad wykonywaniem czynności służbowych. W § 39 Regulaminu więziennego podzielono dozorców na pełniących służbę jako oddziałowi, odźwierni, gospodarczy, sanitarni, kuchenni, w piekarni, pralni, łaźni oraz dziale pracy. Do ich zadań należało czuwanie nad porządkiem i dyscypliną ${ }^{37}$.

Ustawa o organizacji więziennictwa z 1939 r. nie wprowadziła w przedmiocie wewnętrznej struktury więzień znaczących zmian, raczej powtarzała rozwiązania Regulaminu więziennego oraz rozporządzenia o organizacji więziennictwa. Kierownictwo więzień zostało przypisane naczelnikom. Art. 2 ust. 1 ustawy wskazy-

${ }^{37}$ K. Pawlak, op.cit., s. 25. 
wał jako członków składu osobowego więzień naczelników, wyższych i niższych funkcjonariuszy więziennych, kapelanów, nauczycieli, lekarzy, sanitariuszy więziennych oraz personel pomocniczy. Liczba i rodzaj personelu były ustalane przez Ministra Sprawiedliwości, który mianował także inspektorów więziennictwa, naczelników więzień i aresztów. W kwestiach kadrowych dotyczących innych funkcjonariuszy właściwy był Główny Inspektor Straży Więziennej.

\section{NADZÓR PENITENCJARNY}

Nadzór penitencjarny jest jedną z najważniejszych gwarancji legalności oraz prawidłowości wykonywania kary pozbawienia wolności. Należy zaznaczyć, że nadzór penitencjarny oznacza zespół innych instytucji niż klasyczny nadzór administracyjny, który oznacza możliwość władczego oddziaływania na organ nadzorowany bez możliwości wyręczenia organu w wypełnianiu jego funkcji. Syntetycznie rzecz ujmując, nadzór jako pojęcie jest bardzo zbliżony do kontroli38.

$\S 5$ rozporządzenia Ministra Sprawiedliwości z dnia 22 czerwca 1928 r. o wykonaniu rozporządzenia Prezydenta Rzeczypospolitej z dnia 7 marca 1928 r. w sprawie organizacji więziennictwa stanowił, że nadzór penitencjarny obejmuje kontrolę całokształtu życia więziennego, w szczególności czuwanie nad legalnością uwięzienia i prawidłowością wykonania kary. ${ }^{39}$ Uprawnienia z zakresu nadzoru penitencjarnego przysługiwały prokuratorom okręgowym. Ich szczegółowe uprawnienia były skatalogowane w $\S 6$ i $\S 7$ wspomnianego wyżej rozporządzenia. Zgodnie $\mathrm{z}$ literą tych przepisów prokurator okręgowy czuwał nad prawidłowym obliczaniem terminu kary, terminowym zwalnianiem więźniów, segregacją więźniów, w szczególności więźniów nieletnich, celowym i humanitarnym obchodzeniem się z więźniami. Prokurator rozpatrywał zażalenia więźniów na wymiar i zasadność kar dyscyplinarnych. Mógł orzec o ich utrzymaniu, zmianie lub zniesieniu. Prokurator był zobowiązany do czuwania nad zapewnieniem więźniom opieki duchowej, nauczania oraz zorganizowaniem pracy kulturalno-oświatowej w więzieniach. Do kompetencji prokuratora należało również czuwanie nad stanem sanitarnym więzień, wyżywieniem więźniów, prawidłowym stosowaniem systemu progresywnego, zatrudnieniem więźniów oraz wynagrodzeniem za pracę. W przypadku wykrycia zaniedbań lub nadużyć ze strony naczelnika więzienia lub innych funkcjonariuszy miał prawo i obowiązek wszcząć dochodzenie oraz w razie konieczności zawiesić ich w czynnościach służbowych. Prokurator udzielał zgody na zawarcie małżeństwa przez więźniów jemu podległych. Art. 5 ustawy

38 J. Lang, J. Służewski, M. Wierzbowski, A. Wiktorowska, Polskie prawo administracyjne, Warszawa 1995, s. 33.

${ }^{39}$ Dz.U. 1928 Nr 64 poz. 591. 
o organizacji więziennictwa również powierzał uprawnienia z zakresu nadzoru penitencjarnego prokuratorom okręgowym i apelacyjnym. Czynności rozumiane jako nadzór penitencjarny były bardzo zbliżone do tych z rozporządzenia z $1928 \mathrm{r}$.

Inaczej przedstawiała się kwestia nadzoru administracyjnego w systemie penitencjarnym. Początkowo uprawnienia określane jako nadzór administracyjny przysługiwały Dyrekcjom Okręgowym. Po likwidacji Dyrekcji Okręgowych w październiku $1921 \mathrm{r}$. przestał istnieć organ pośredni między więzieniami a Departamentem Karnym. Funkcje nadzorcze były realizowane przez prokuratorów w ramach nadzoru penitencjarnego. W 1924 r. utworzono trzy okręgi rewizyjne w celu zapewnienia efektywnej kontroli więzień, dwa dla terenów byłego zaboru rosyjskiego oraz jeden dla terenów byłego zaboru niemieckiego i austriackiego. W 1930 r. liczbę okręgów rewizyjnych zwiększono do pięciu ${ }^{40}$. Na podstawie $\S 2$ i § 3 zarządzenia Ministra Sprawiedliwości z dnia 15 stycznia 1936 r. ustanowiono okręgi inspekcyjne kontroli sanitarnej i lecznictwa w więzieniach ${ }^{41}$.

Art. 6 rozporządzenia Prezydenta Rzeczypospolitej z 1928 r. stanowił, że naczelny nadzór i kierownictwo nad więzieniami i zakładami wychowawczo-poprawczymi wykonuje Minister Sprawiedliwości. Wyraźna ewolucja w pojmowaniu nadzoru nad więzieniami była widoczna w art. 1 ust. 2 ustawy o organizacji więziennictwa z 1939 r., który powierzał bezpośredni nadzór nad więzieniami i aresztami Głównemu Inspektorowi Straży Więziennej, inspektorom więziennictwa delegowanym przez niego lub innym wyższym funkcjonariuszom Straży Więziennej.

\section{PERSONEL WIĘZIENNY}

Status pracowników więziennictwa opierał się początkowo na przepisach ustawy z dnia 17 lutego 1922 r. o państwowej służbie cywilnej ${ }^{42}$. Ustawa dzieliła pracowników na dwie kategorie: urzędników i niższych funkcjonariuszy ${ }^{43}$. Do grupy urzędników zaliczano inspektorów więziennych, podinspektorów, naczelników więzien, zastępców naczelników, asystentów więziennych, adiunktów kancelaryjnych, kancelistów, registratorów oraz rachmistrzów ${ }^{44}$. Grupa niższych funkcjonariuszy składała się ze starszych dozorców, dozorców oraz pomocniczych dozorców więziennych ${ }^{45}$. Co do zasady urzędnicy powinni byli mieć średnie wykształcenie, natomiast niżsi funkcjonariusze musieli wykazać się znajomością czytania i pisania $\mathrm{w}$ języku polskim oraz czterech podstawowych działań

\footnotetext{
${ }^{40}$ K. Pawlak, op. cit. s. 10.

${ }^{41}$ Dz.Urz. Nr 2/36.

${ }^{42}$ Dz. U. 1922 Nr 21, poz. 164.

${ }^{43}$ J. Migdał, op.cit., s. 273.

${ }^{44}$ K. Pawlak, op.cit., s. 26.

${ }^{45}$ Ibidem.
} 
arytmetycznych ${ }^{46}$. Na podstawie przepisów rozporządzenia Prezydenta Rzeczypospolitej z dnia 23 sierpnia 1932 r. o Straży Więziennej utworzono Korpus Straży Więziennej ${ }^{47}$. Art. 10 rozporządzenia dzielił pracowników więziennictwa na funkcjonariuszy wyższych i niższych ${ }^{48}$. Wśród wyższych funkcjonariuszy przepisy rozporządzenia wymieniały Głównego Inspektora Straży Więziennej, inspektorów, nadkomisarzy, komisarzy, podkomisarzy oraz aspirantów. Z kolei art. 12 rozporządzenia zaliczał do niższych funkcjonariuszy Straży Więziennej przodowników, starszych strażników oraz strażników.

Przy mianowaniu wyższych funkcjonariuszy pierwszeństwo mieli kandydaci z wyższym wykształceniem oraz oficerowie przechodzący do pracy w więziennictwie bezpośrednio z czynnej służby wojskowej. W przypadku zaś mianowania niższych funkcjonariuszy - podoficerowie i szeregowcy zawodowi w czynnej służbie (art. 13 rozporządzenia). Art. 14 formułował wymagania, które musieli spełnić kandydaci na stanowiska niższych funkcjonariuszy Straży Więziennej. Powinni byli posiadać: polskie obywatelstwo, nieskazitelną przeszłość, wiek od 21 do 35 lat, odpowiedni stan fizyczny i umysłowy, zdolność do czynności prawnych, dokładną znajomość języka polskiego w mowie i piśmie oraz ukończenie szkoły powszechnej udowodnione świadectwem. Kandydaci na wyższych funkcjonariuszy Straży Więziennej musieli legitymować się świadectwem potwierdzającym wykształcenie średnie ogólnokształcące lub zawodowe oraz zdanie stosownych egzaminów. Do Straży Więziennej nie mogły zostać przyjęte osoby, przeciwko którym toczyło się sądowe postępowanie karne o przestępstwa ścigane $\mathrm{z}$ urzędu, postępowanie upadłościowe albo postępowanie w przedmiocie ubezwłasnowolnienia. Tak samo do Straży Więziennej nie można było przyjąć osoby, która popełniła przestępstwo motywowane chęcią zysku (art. 18 rozporządzenia). Wyższych funkcjonariuszy mianował Minister Sprawiedliwości, natomiast niższych Główny Inspektor Straży Więziennej.

\section{ODPOWIEDZIALNOŚĆ DYSCYPLINARNA FUNKCJONARIUSZY}

Za przekroczenia służbowe pracownicy administracji więziennej byli początkowo pociągani do odpowiedzialności dyscyplinarnej uregulowanej w przepisach ustawy o państwowej służbie cywilnej ${ }^{49}$. Nowy mechanizm odpowiedzialności dyscyplinarnej wprowadzało rozporządzenie Ministra Sprawiedliwości z dnia 15 października 1932 r. o postępowaniu dyscyplinarnym przeciw funkcjonariuszom

\footnotetext{
${ }^{46} \mathrm{~K}$. Pawlak, Za kratami więzień i drutami obozów. Zarys dziejów więziennictwa w Polsce, Kalisz 1999, s. 61.

${ }^{47}$ Ibidem.

${ }^{48}$ Dz.U. 1932 Nr 74 poz. 667.

${ }^{49}$ K. Pawlak, op.cit., s. 29.
} 
Straży Więziennej ${ }^{50}$. Właściwą w sprawach wyższych funkcjonariuszy Straży Więziennej była Komisja dyscyplinarna przy Ministrze Sprawiedliwości dla wyższych funkcjonariuszy Straży Więziennej. Sprawy dotyczące niższych funkcjonariuszy Straży Więziennej rozpatrywały Komisje dyscyplinarne przy prokuraturach poszczególnych sądów apelacyjnych. Kary dyscyplinarne, które mogły być orzekane zawierał art. 75 rozporządzenia Prezydenta Rzeczypospolitej o Straży Więziennej. Były to kary: aresztu od jednego do czternastu dni, degradacji o jeden stopień, zwolnienia ze służby oraz wydalenia ze służby. Prawo nakładania kar dyscyplinarnych wobec wszystkich funkcjonariuszy przysługiwało Ministrowi Sprawiedliwości. Główny Inspektor Straży Więziennej mógł nakładać kary dyscyplinarne na niższych funkcjonariuszy, natomiast wobec wyższych funkcjonariuszy wyłącznie karę aresztu. Art. 82 rozporządzenia stanowił, że karę dyscyplinarną można wymierzyć dopiero po zasięgnięciu opinii właściwej komisji dyscyplinarnej. Od orzeczenia dyscyplinarnego nie przysługiwało odwołanie.

\section{NAUKA PENITENCJARYSTYKI}

Tradycja międzynarodowych kongresów penitencjarnych sięga XIX wieku. Aktywność polskich przedstawicieli podczas obrad kongresów była znacząca. Ze względu na przedmiot artykułu opracowanie będzie się skupiać na kongresach okresu międzywojennego.

Pierwszy z kongresów II serii odbywał się w Londynie w $1925 \mathrm{r}^{51} \mathrm{~W}$ literaturze podkreśla się, że inicjował on zmiany w światowej penitencjarystyce ${ }^{52}$. Polska delegacja miała sposobność brać udział w dyskusji oraz zapoznać się z nowymi prądami w dziedzinie prawa karnego ${ }^{53}$. Funkcje, jakie polscy reprezentanci pełnili $\mathrm{w}$ administracji państwowej uzasadniają twierdzenie, że doświadczenia wyniesione z obrad kongresu mogły mieć wpływ na kształt rozwiązań przyjętych w polskim prawie penitencjarnym. Dla przykładu, Stanisław Emil Rappaport, wchodzący w skład polskiej delegacji, był również członkiem i sekretarzem komisji kodyfikacyjnej przygotowującej projekt Kodeksu karnego ${ }^{54}$. Realizacja postulatów kongresu londyńskiego $\mathrm{w}$ polskim systemie więziennym przejawiała się chociażby w kształtowaniu się nowej klasyfikacji instytucji izolacyjnych, w tym więzień specjalnych. ${ }^{55}$

${ }^{50}$ Dz.U. $1932 \mathrm{Nr} 92$ poz. 800.

${ }^{51}$ Kongresy II serii to synonim kongresów okresu międzywojennego.

52 J. Górny, Rola międzynarodowych kongresów penitencjarnych w rozwoju teorii i praktyki wykonania kary, Warszawa 1980, s. 146.

${ }^{53}$ Ibidem.

${ }^{54}$ Ibidem, s. 147.

${ }^{55}$ Ibidem, s. 148 . 
Kolejny międzynarodowy kongres penitencjarny miał miejsce w Pradze w 1930 r. Udział polskiej delegacji zaznaczył się inspirującymi wystąpieniami na tematy nurtujące ówczesną penitencjarystykę. Referaty polskich przedstawicieli dotyczyły profilaktyki i prewencji, znaczenia personelu więziennego w procesie wykonywania kary więzienia środków ochronnych, ogólnych zasad prawa karnego oraz zasad wymierzania kar łącznych. ${ }^{56} \mathrm{~W}$ skład polskiej delegacji wchodziło 15 reprezentantów ze Stanisławem Emilem Rappaportem jako przewodniczącym na czele. ${ }^{57}$

W 1935 r. rozpoczął obrady berliński kongres penitencjarny, ostatni w okresie międzywojennym. Funkcję przewodniczącego polskiej delegacji pełnił prof. Stefan Glaser ${ }^{58}$. Polscy przedstawiciele zaprezentowali cztery odczyty na temat legislacji w sprawach karnych, penitencjarnych, prewencyjnych oraz przestępczości wśród nieletnich. ${ }^{59}$ Podczas obrad kongresów penitencjarnych poruszano większość kwestii istotnych z punktu widzenia prawa i polityki penitencjarnej. W ich pracach uczestniczyły osoby reprezentujące wymiar sprawiedliwości oraz środowiska akademickie.

Przystępując do oceny organizacji systemu penitencjarnego II Rzeczypospolitej należy mieć na uwadze kilka faktów. Podstawowym problemem był brak środków finansowych w więziennictwie, podczas gdy stan więzień przejętych po państwach zaborczych wymagał znacznych inwestycji. ${ }^{60}$ Uwarunkowania historyczne wymusiły budowę systemu penitencjarnego od podstaw, a nie w sposób ewolucyjny ${ }^{61}$ Należy docenić fakt, że polskim władzom udało się zorganizować nowoczesny system penitencjarny w trudnych warunkach. W dobrym świetle stawia także polskiego ustawodawcę wprowadzanie zmian w aktach normatywnych dotyczących więziennictwa pod wpływem zaleceń międzynarodowych kongresów penitencjarnych. Oczywiście występowały także problemy, które nie zostały rozwiązane w sposób zadowalający. W tym miejscu warto wspomnieć chociażby kwestię przeludnienia więzień oraz statusu prawnego więźniów politycznych. Biorąc pod uwagę stan infrastruktury więziennej, dostępne zasoby finansowe oraz tempo organizacji systemu penitencjarnego, system więzienny II Rzeczypospolitej należy ocenić pozytywnie.

\footnotetext{
56 K. Pawlak, op.cit., s. 15.

57 Ibidem.

58 J. Górny, op.cit., s. 151.

59 Ibidem.

${ }^{60}$ J. Migdał, op. cit., 15.

61 Ibidem.
} 


\section{ORGANIZATION OF THE PRISON SYSTEM IN POLAND BETWEEN 1918 AND 1939}

\section{Summary}

Recovering after the partition period, the Polish state faced many challenges and one of them definitely was the penitentiary policy. Among the legacies of the period of partition were three different prison systems and different regulations in the field of penitentiary law. The main task of the Polish legislator was to unify the national prison system by taking into account not only the specificity of the existing solutions but also the achievements of the contemporary penitentiary.

The purpose of the paper is to present the history of the organization of the Polish prison system between 1918 and 1939 in more detail. It is necessary to describe the political situation in the Polish lands during the final years of the First World War which significantly influenced the different character of the institutions in the Polish territories. The reflections on the organization of the Polish prisons during the interwar period will be centered around the following issues: taking over prisons by the Polish authorities, systematic unification of the structure of the prison system, prison stratification, the legal status of the prison staff, the education system of prison officers as well as the system of supervision of the execution of prison sentences.

The literature on the subject highlights the importance of the international penitentiary congresses for the development of the penitentiary law in the interwar period. The contribution of the Polish delegations to the works of the London, Prague and Berlin congresses was significant. Taking into account the importance of the resolutions of the congresses, the paper will present the participation of Poles in the debates.

Research methodology is based on the analysis of normative acts devoted to the organization of the Polish prison system between 1918 and 1939. The following are among the analyzed elements: the decree on the provisional prison regulations of the $8^{\text {th }}$ of February 1919, the regulation by the President of the Republic of Poland on the organization of the prison system of the $7^{\text {th }}$ of March 1928, the regulation by the Minister of Justice on the rules and regulations of the prison system of the $20^{\text {th }}$ of June 1931, the regulation by the President of the Republic of Poland on the Prison Guard of the $23^{\text {rd }}$ of August 1932, and the act on the organization of the prisoner system of the $26^{\text {th }}$ of July 1939. Memories of persons involved in prison activity and publications pertaining to penitentiary law issues from the interwar period were also used to prepare this article.

\section{ORGANISATION DU RÉGIME PÉNITENTIAIRE POLONAIS (1918-1939)}

\section{Résumé}

Renaissant après la période des partages, l'État polonais a fait face à de nombreux défis, dont l'un était certainement la politique pénitentiaire. Trois systèmes pénitentiaires différents et des réglementations variées dans le domaine du droit pénitentiaire étaient l'héritage des régimes des occupants. La tâche principale du législateur polonais était 
d'unifier le système pénitentiaire national, en tenant compte de la spécificité non seulement des solutions existantes, mais aussi des réalisations de la science pénitentiaire de l'époque.

L'objectif de cette étude est de mettre en lumière l'histoire de l'organisation du système pénitentiaire polonais dans les années 1918-1939. Nos réflexions engagées à cet égard portent sur des questions telles que la prise en charge des prisons par les autorités polonaises, l'unification systématique des structures pénitentiaires, la stratification des prisons, le statut juridique du personnel pénitentiaire, le système d'éducation des agents et le système de contrôle de l'exécution des peines d'emprisonnement. La littérature souligne l'importance des congrès pénitentiaires internationaux pour le développement du droit pénitentiaire dans l'entre-deux-guerres. La contribution des délégués polonais aux congrès de Londres, Prague et Berlin était significative. Tenant compte de l'importance des résolutions des congrès, l'article présente la participation des Polonais à leurs débats.

Notre méthodologie de travail repose sur l'analyse des actes normatifs consacrés à l'organisation du système pénitentiaire polonais dans les années 1918-1939, notamment: le décret du 8 février 1919 sur les règlements pénitentiaires provisoires, le règlement du Président de la République du 7 mars 1928 sur l'organisation du système pénitentiaire, l'arrêté du Ministre de la Justice du 20 juin 1931 sur le règlement de la prison, le règlement du Président de la République du 23 août 1932 sur la garde de prison ainsi que la Loi sur l'organisation du système pénitentiaire du 26 juillet 1939.

Les mémoires des personnes impliquées dans le fonctionnement du système pénitentiaire et les publications consacrées au droit pénitentiaire de l'entre-deux-guerres ont également servi de base à l'élaboration de cet ouvrage. 
